\title{
Enhancement of Honey Production of Apis mellifera L. Colonies in Egypt
}

\author{
Zaghloul, A . O., Nagda A. El-Sayed, Nadia M. Hassona, A. K. Mourad and B. A. Abdel-Razek 1
}

\begin{abstract}
Two different methods were carried out as an attempt to increase the honey production of $A$. mellifera colonies (Hybrid) in Egypt. The first method was conducted during winter of 2015/2016 season, includes and three different diets; skimmed soybean, (A) chickpea, (B) and yellow corn flour(C). These supplementary diets were used to fed bee colonies during dearth period to increase their production. Results revealed an increase in sealed brood yield to 1290.0 \pm 48.47 inch $^{2}$ with daily egg laying of 2956.2 \pm 111.1 eggs/colony for colonies fed on soybean diet (A), which was the best diet as compared to chickpeas (B) and yellow corn diets (C). In addition, diet (A) showed the highest number of queen cells $(138.6 \pm 5.65$ cell/colony) with the highest cell length (14.9 $\pm 0.38 \mathrm{~mm} /$ queen cell). Moreover, these colonies showed the highest honey production $(6.82 \pm 0.33 \mathrm{Kg} /$ colony) during the period of citrus blossom season.
\end{abstract}

A queen exclusion system, the second method, was conducted to increase honey production through out three nectar seasons of citrus, clover and cotton. Total honey was $91.45 \mathrm{~kg} / 10$ colonies with amean of $9.15 \mathrm{~kg} /$ colony. In clover season, honey production was $53.78 \mathrm{~kg} / 10$ colonies, with a mean of $5.38 \mathrm{~kg} /$ colony, while in cotton season the colonies produced the least amount of honey of $43.14 \mathrm{~kg} / 10$ colonies with a mean of $4.31 \mathrm{~kg} /$ colony. There were highly significant differences among the colonies that provided with the queen excluder system on one side and the other control colonies on the other side.

Statistical wise, the difference was sigmi ficamt between queen exclusion system ant the control.

Keywords: supplementary diets, soybean, chickpeas, yellow corn flour, queen cells, bees honey, sealed brood, egg lying, queen length, queen excluder.

\section{INTRODUCTION}

Managed honey bees have economic importance with hive products such as honey, pollen, wax, propolis, and royal jelly (Maheshwari, 2003).

Honey bees, Apis mellifera, depend mainly on nectar and pollen as sources of nutrients. Nectar provides bees with carbohydrates, while pollen supplies them with the remaining dietary requirements such as proteins, lipids, vitamins, and minerals (Brodschneider and Crailsheim, 2010).). Lack of pollens in the field is a critical problem for beekeepers. Supplying bee colonies with an alternative artificial source of protein, like pollen substitutes, is essential to boost colony survival and development (Herbert, 1992). Honey production is an important target for all beekeepers worldwide. They try to find the best methods to increase the products of bee colonies. Some beekeepers use different supplementary diets and others use different methods to increase honey by using queen exclusion system. Four kinds of supplementary diets of soybean, maize, gram, and sugar were tested to evaluate their performance on colonies activity during the period of August to January. Honey produced after the treatment with gram was significantly better than that produced by bees fed on other pollen supplementary diets (Mahmood et al., 2013). Pande and Karnatak (2014) tested the effect of certain chickpea, green gram and horse gram. soybean, maize, wheat, and gram as horse powder mixed with honey, water and soybean, which indicated the best way for visiting bees. Usha et al. (2014)and Aly et al. (2014) examined certain supplementary diets of gram, bean, pea, fenugreek, coriander, cumin, anise, caraway, fennel, white kidney beans rice, and oats seeds flours calculated the percentage of consumption of each one in comparison to they sugar candy, which has been used as a control. Fermented gluten meal, fermented soybean meal, soybean meal and gluten meal as supplementary diets were used by Rezaei et al. (2015) to evaluate their effects on colonies activity compared with pollen and sugar solution, as a control treatments. Amro et al. (2016) used five supplementary isolated diet proteins of soybean, pod powder, date pasta, Feedbee ${ }^{\circledR}$ (a nutritious pollen supplement), and corn gluten compared with control colonies fed on pollen in relation to their effect on certain physiological parameters, rearing activity, and consumption amount. Feedbee ${ }^{\circledR}$ was able to enhance brood rearing,

Queen excluder is a very important method to increase honey production during peak seasons, Moeller (1980) and, Morris (2012) indicated that queen exclusion has positively affected honey yield, and found that its application in one colony was better than in two colonies. Nuru et al. (2013) found that colonies with queen exclusion produced more honey and brood than the control, then also showed a balance between brood production and honey yield in peak seasons.

Therefore, two methods were used in this study to increase honey yield. The first method used three different supplementary diets (skimmed soybean, chickpea, and yellow corn flour) to evaluate their effect

\footnotetext{
${ }^{1}$ Plant Protection Dept., Faculty of Agric. (Saba Basha),

Alex. Univ., Egypt

Received June 22, 2017, Accepted August 14, 2017.
} 
on colonies activity, food consumption rate and, food conversion. The second method used the queen exclusion system to evaluate its effect on honey yield.

\section{MATERIALS AND METHODS}

This research has been carried out at a commercial apiary in Rosetta region, $40 \mathrm{~km}$ East Alexandria city in collaboration with the laboratory of Plant Protection, Faculty of Agriculture, Saba -Basha, Alexandria University.

\section{1- Experiments}

\section{Experiment 1}

Three different diets were prepared during the period of mid-November 2015 and offered continuously to colonies during the dearth period until early March 2016. Twenty Langstroth hives were selected similarily with respect to the number of frames with presented bees covering them. Frames were divided into Four groups; 5 colonies Frames for each treatment plus the control. The three supplementary materials, diets were skimmed soybean, chickpea and yellow corn powders, and each one was composed of $100 \mathrm{~g}$ of the main material mixed with $250 \mathrm{~g}$ sugar, $50 \mathrm{~g}$ dry yeast, $10 \mathrm{~g}$ cinnamon and $90 \mathrm{~g}$ honey.

The components were sieved properly to get rid of solids materials that bees cannot digest. The refined materials were kept in polyethylene bags in dry conditions until use. Each diet was placed on the frames of each experimented colony after opening a big hole to facilitate the way of bees for feeding.

\section{Experiment II}

A simple device; named "the queen excluder separator", has been used with three nectar sources of citrus, clover, and cotton. For each nectar, twenty colonies were used, and grouped into two groups; 10 colonies represent the nectar treatment and 10 colonies represented the control. This technique consisted of a queen excluder cage with the same dimensions of the colony frame to confine tightly the queen on two frames only inside the system (cage). This device was adopted after 10 days from the onset of the nectar season Frames with sealed brood were caged to allow workers to use the other free frames of the colony to be filled with honey after setting free queen in the main nectar season.

The afore-mentioned practical experiments were undertaken to increase the honey yield in three season of (citrus, clover, and cotton) by bee workers in collecting considerable quantities of nectar and convert it into honey inside the hives.

\section{2- Evalution of the biological activities}

\subsection{Honey production in spring of 2016 seasons}

Colonies provided by the supplementary diets were compared with the control. Honey was collected $(\mathrm{kg})$ in spring of 2016 season (citrus season) from each colony and compared with that produced in winter of the same seasons

\subsection{Evaluation of sealed brood and egg laying in spring of 2015 and 2016 seasons}

Sealed brood in sprung of 2015 and 2016 seasons was measured by using the inch square frame method. Each sealed brood frame was taken from each colony after removing the bees, and then the square inch frame was put on it. The number of square inches of the brood bee was calculated. The number of daily egg laying was calculated by the following equation:

The number of daily eggs $=$ the number of sealed brood( inches) ${ }^{2} \mathrm{X}(27.5 / 12)$

And compared to the control colonies and length ( Hassona. (2006)

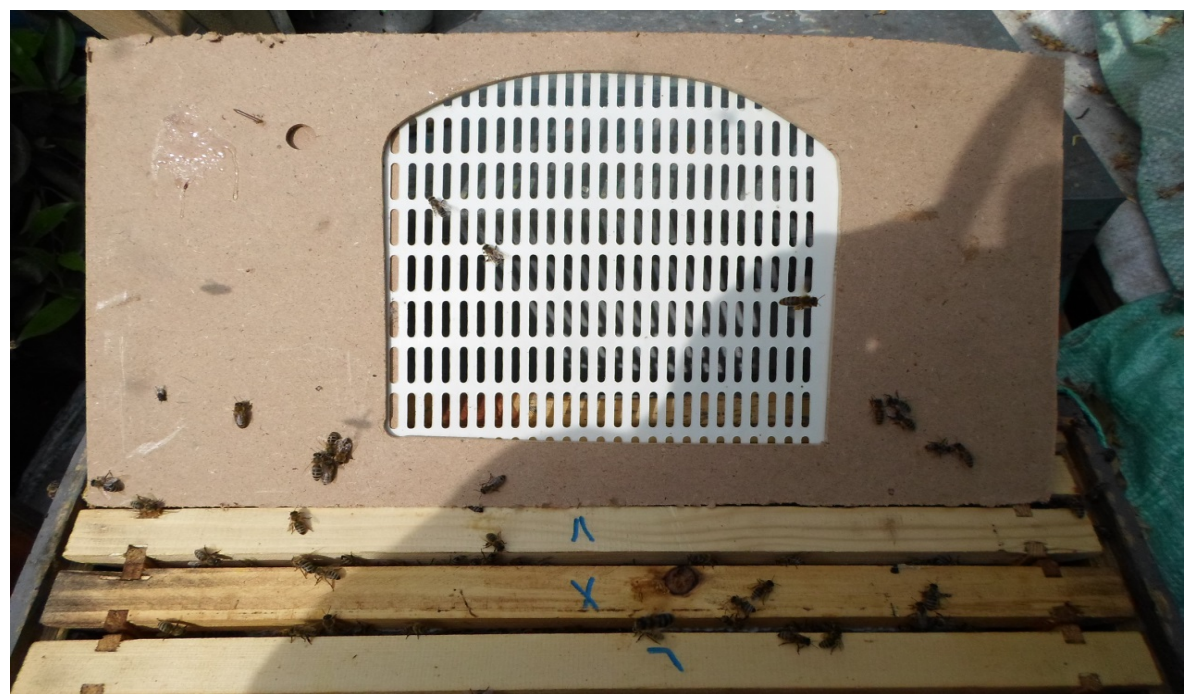

Photo 1. Colony with the queen excluder 


\subsection{Number and length of queen cells in spring of 2016 seasons}

In the beginning of spring season of 2016, many queen cells appeared in colonies provided with diets during winter season. These queen cells were counted and measured in millimeters by a ruler. Their number and length have been compared with the control colonies.

\subsection{The queen excluder system}

Queen excluder system was employed in three nectar flows of citrus, clover and cotton. Simply, this device of the queen excluder has been used in one colony with 10 frames to separate only two frames with nectar from those with brood and a young queen of 9-months age utmost. The device was used approximately within 1015 days from the start of the nectar flow season and compared with queen excluder without this device, the control (Photo1).

\section{3-Statistical analysis}

SAS program was used for data analysis using, and means were analysis of variances (F. value) was used where L.S.D and standard deviations. The correlation among some treatments was also calculated. Regression equations were used to calculate the differences among performed treatments.( Data wera analyzed suing GIM procedure according to SAS ,2004)

\section{RERSULTS AND DISCUSSION}

\section{1- Effect of supplementary diets on the biological activity of $\boldsymbol{A}$. mellifera colonies}

As shown in Table (1), results of revealed that colonies fed on skimmed soybean diet (diet A) consumed $46.00 \pm 16.07 \mathrm{~g}$ out of $500 \mathrm{~g}$ of the diet with a mean conversion rate of $0.64 \pm 0.23 \mathrm{~g}$, which led to both sealed brood mean of $77.60 \pm 12.63 \mathrm{inch}^{2}$, and mean daily egg laying of $130.12 \pm 13.25$ for each colony. Colonies fed on chickpeas diet (diet B) consumed 44.00 $\pm 14.92 \mathrm{~g}$ out of $500 \mathrm{~g}$, with a conversion rate of $0.69 \pm$ $0.24 \mathrm{~g}$ that produced sealed brood of $68.40 \pm 11.41$ inch $^{2}$ with daily egg laying of $114.99 \pm 12.09$.

The another group of colonies fed on yellow corn diet (diet C) consumed $42.00 \pm 14.20 \mathrm{~g}$ with a conversion rate of $0.66 \pm 0.22 \mathrm{~g}$ reflected on sealed brood mean of $67.20 \pm 10.97 \mathrm{inch}^{2}$ and daily egg laying of $113.63 \pm 11.94$ for each colony. In regards to the control colonies (D), the mean sealed brood was $68.20 \pm$ $10.54 \mathrm{inch}^{2}$ and the mean number of daily egg laying was $113.64 \pm 10.23$ for each colony. The other diets (B and C) There were significant differences between each diet and the control only in March. In December, with the continous feeding on different diets, colonies fed on diet (A) consumed $228.0 \pm 17.55 \mathrm{~g}$ with a conversion rate of $1.78 \pm 0.052 \mathrm{~g}$. After that, colonies produced mean sealed brood of $126.6 \pm 7.28 \mathrm{inch}^{2}$ with a mean daily egg laying of $290.1 \pm 16.68$ for each colony. As for colonies fed on diet (B), these figures were $223.0 \pm$ $11.14 \mathrm{~g}, 1.79 \pm 0.048 \mathrm{~g}, 126 \pm 8.16 \mathrm{inch}^{2}$, and $288.72 \pm 18.70$ respectively. The third group of colonies fed on diet (C), consumed $221.0 \pm 16.31 \mathrm{~g}$ with a conversion rate of $1.54 \pm 0.052 \mathrm{~g}$, which lead to sealed brood mean of $142.5 \pm 6.88 \mathrm{inch}^{2}$ and the mean daily eggs laying of $324.72 \pm 6.22$ for each colony. contrary, colonies produced the mean of sealed brood of $127 \pm 5.38$ inch $^{2}$ and the mean of daily eggs laying of $291 \pm 12.34$ eggs/ day for each control colony. Statistical analysis showed a significant cant differences among the three groups of diets and the control.

Similarly, in January and February, the mean figures of consumption and related biological activities for the first group of colonies that continued to feed on $\operatorname{diet}$ (A) reached higher levels rather than the preceding months of November and December where food consumption was $426.67 \pm 16.80 \mathrm{~g}$ with a conversion rate of $1.35 \pm$ $0.07 \mathrm{~g}$, mean yield of $338 \pm 30.7 \mathrm{inch}^{2}$, and mean daily egg laying $774.54 \pm 70.40$ for each colony.

The second group of colonies continued feeding on $\operatorname{diet}(\mathrm{B})$, consumed $414.33 \pm 15.76 \mathrm{~g}$ with a conversion rate of $1.37 \pm 0.05 \mathrm{~g}$ It also showed in an increase mean space or area of sealed brood $\left(310 \pm 18.95 \mathrm{inch}^{2}\right)$ and daily egg lying to $710.41 \pm 43.43$ for each colony. The third group fed on diet (C) consumed $442.60 \pm 15.55 \mathrm{~g}$ with a conversion rate of $1.45 \pm 0.05$ g leading to a mean space of $312.7 \pm 19.79 \mathrm{inch}^{2}$ sealed brood and a mean number of daily was $730.24 \pm 48.67$ egg laying for each colony. In control colonies, the mean of sealed brood was $288 \pm 21.81 \mathrm{inch}^{2}$ and the mean number of egg daily laying was $661.48 \pm 50.0$ for each colony. The comparison among the three different diets groups and the control illustrated significant differences (Table 1).

Likewise, in February, the first fed colony group (diet A), the mean yield of sealed brood increased to $1005 \pm 51.9 \mathrm{inch}^{2}$ and the mean of daily egg laying was $2303.1 \pm 118.94$ for each colony. The second group (diet B) reflected sealed brood mean of $679.0 \pm 46.4$ inch $^{2}$ and daily egg laying of $1556 \pm 106.31$ for each colony. The third group (diet C) produced mean sealed brood of $687.0 \pm 33.2 \mathrm{inch}^{2}$ and egg daily laying of $1413.44 \pm 155.1$ for each colony. The control colonies showed a mean sealed brood yield of $628.0 \pm 41.1 \mathrm{inch}^{2}$ and a mean daily egg laying yield of $1439.1 \pm 94.17$ for each colony. 
Table 1. Effect of supplementary diets on the biological activities of bees during winter season of 2015/2016

\begin{tabular}{|c|c|c|c|c|c|}
\hline \multirow{2}{*}{$\begin{array}{c}\text { Experimental } \\
\text { months }\end{array}$} & \multirow{2}{*}{$\begin{array}{c}\text { Supplementary } \\
\text { diet }\end{array}$} & \multicolumn{2}{|c|}{ Biological activities } & \multirow{2}{*}{$\begin{array}{l}\text { Mean amount of } \\
\text { food consumption } \\
\text { (g) }\end{array}$} & \multirow{2}{*}{$\begin{array}{c}\text { Mean food } \\
\text { Conversion } \\
\text { (g)*** }\end{array}$} \\
\hline & & $\begin{array}{l}\text { Mean area of } \\
\text { sealed worker } \\
\text { brood }\left(\text { inch }^{2}\right)\end{array}$ & $\begin{array}{c}\text { Mean No. of } \\
\text { laying } \\
\text { eggs/day/queen }\end{array}$ & & \\
\hline \multirow[t]{5}{*}{ November } & (A)\# & $77.60^{\mathrm{a}} * \pm 12.63$ & $130.12 \pm 13.25$ & $46.00 \pm 16.07$ & $0.64 \pm 0.23$ \\
\hline & (B) & $68.40^{\mathrm{b}} \pm 11.41$ & $114.99 \pm 12.09$ & $44.00 \pm 14.92$ & $0.69+0.24$ \\
\hline & (C) & $67.20^{\mathrm{b}} \pm 10.97$ & $113.63 \pm 11.94$ & $42.00 \pm 14.20$ & $0.66 \pm 0.22$ \\
\hline & Control (D) & $68.20^{\mathrm{b}} \pm 10.54$ & $113.64 \pm 10.23$ & 0.00 & 0.00 \\
\hline & L.S.D & 14.926 & - & - & - \\
\hline \multirow[t]{5}{*}{ December } & (A) & $126.6 \pm 7.28$ & $290.1 \pm 16.68$ & $228.0 \pm 17.55$ & $1.78 \pm 0.052$ \\
\hline & (B) & $126 \pm 8.16$ & $288.72 \pm 18.70$ & $223.0 \pm 11.14$ & $1.79 \pm 0.048$ \\
\hline & (C) & $142.5 \pm 6 . \mathrm{S} 8$ & $324.72 \pm 16.22$ & $221.0 \pm 16.31$ & $1.54 \pm 0.052$ \\
\hline & Control (D) & $127 \pm 5.38$ & $291.0 \pm 12.34$ & 0.00 & 0.00 \\
\hline & L.S.D & - & - & - & - \\
\hline \multirow[t]{5}{*}{ January } & (A) & $338.0 \pm 30.7$ & $774.54 \pm 70.40$ & $426.67 \pm 16.80$ & $1.35 \pm 0.07$ \\
\hline & (B) & $310.0 \pm 18.95$ & $710.41 \pm 43.43$ & $414.33 \pm 15.76$ & $1.37 \pm 0.05$ \\
\hline & (C) & $312.7 \pm 19.79$ & $730.24 \pm 48.67$ & $442.60 \pm 15.55$ & $1.45 \pm 0.05$ \\
\hline & Control (D) & $288.9 \pm 21.8 \mathrm{I}$ & $661.48 \pm 50.0$ & 0.00 & 0.00 \\
\hline & L.S.D & - & - & - & - \\
\hline \multirow[t]{5}{*}{ February } & (A) & $1005.0^{\mathrm{a}} \pm 51.9$ & $2303.1 \pm 118.94$ & 0.00 & 0.00 \\
\hline & (B) & $679.0^{\mathrm{b}} \pm 46.4$ & $1556 \pm 106.31$ & 500.00 & $0.92 \pm 0.04$ \\
\hline & (C) & $687.0^{\mathrm{b}} \pm 33.2$ & $1413.44 \pm 155.1$ & 0.00 & 0.00 \\
\hline & Control (D) & $628.0^{\mathrm{b}} \pm 41.1$ & $1439.0 \pm 94.17$ & 0.00 & 0.00 \\
\hline & L.S.D & 125.3 & - & 0.00 & 0.00 \\
\hline \multirow[t]{5}{*}{ March } & (A) & $1290.0^{\mathrm{a}} \pm 48.47$ & $2956.2 \pm 111.1$ & 0.00 & 0.00 \\
\hline & (B) & $1146.0^{b} \pm 40.57$ & $2626.2 \pm 92.97$ & 0.00 & 0.00 \\
\hline & (C) & $1194^{\mathrm{ab}} \pm 31.87$ & $2736.2 \pm 73.04$ & 0.00 & 0.00 \\
\hline & Control (D) & $998.0^{c} \pm 29.7$ & $2287.0 \pm 68.13$ & 0.00 & 0.00 \\
\hline & L.S.D & 115.1 & - & 0.00 & 0.00 \\
\hline
\end{tabular}

\#Soybean (A), chickpeas (B) and yellow corn (C)

*Means followed with the same letter in a column under each experimental month are not significantly different.

** Food conversion $=$ amount of consumed food/sealed worker brood.

Results indicated significant differences between the first group and all others groups in their biological activities (Table 1). The highest mean of sealed brood and number of egg lying was related to the first group fed on diet (A). Unexpectedly, although bees finished feeding on diets $\mathrm{A}, \mathrm{B}$, and $\mathrm{C}$ in March, results revealed maximum increase in feeding activity of sealed brood and egg laying with colonies fed on $\operatorname{diet}(\mathrm{A})$, where the mean of sealed brood was $1290.0 \pm 48.47 \mathrm{inch}^{2}$ and egg laying $2956.2 \pm 111.1$ for each colony. Colonies which were fed on diet (B) had mean sealed brood of
$1146 \pm 40.57$ inch $^{2}$ and egg lying of $2626.2 \pm 92.97$ for each colony. The third group of colonies fed on diet (C) showed a mean sealed brood of $1194 \pm 31.87 \mathrm{inch}^{2}$ and mean egg laying of $2736.2 \pm 73.04$ for each colony. Whereas, the control colonies less showed sealed brood yield of $998 \pm 29.7 \mathrm{inch}^{2}$ and a reduction in daily eggs laying of $2287 \pm 68.13$. There were significance differences among the applied diets. In conclusion results revealed that the highest number of laying eggs was for colonies fed on skimmed soybean diet (A), followed by colonies fed on yellow corn diet (C), and 
then chickpea diet (B). The entire supplement diets proved better production of daily egg lying than control group in the beginning of citrus season. These results agreed with those of Aly et al. (2014), in the sense that all colonies fed on supplementary diets produced more brood areas than control colonies. On the contrary, pollen supplemented diets produced more brood in early spring than other colonies (Manila and Otis, 2006). Soy bean flour diets built up quickly and increased colonies because soybean diet had highest brood than other colonies fed on other diets (Sihag and . Manisha, 2013), and this might be due to that soybean flour contain higher nutrient elements.

\section{2- Effect of feeding diets on queens cell number and length}

Results in Table (2) indicated that colonies fed on diet (A) through spring period of 2016 season produce 138.6 \pm 5.65 queen cells/colony, mean length of $14.9 \pm 0.38 \mathrm{~mm} /$ queen cell. Cell produced the least mean quean cells number of queen cell $32.00 \pm 17.84$. Colonies fed on diet (B) a mean length of $10.1 \pm 0.21 \mathrm{~mm} /$ queen/ cells. On the otherhand, colonies fed on diet (C) produced the highest mean number of queen cells (114.6 \pm 5.62 cells/colony) with a mean length of $12.1 \pm 0.50 \mathrm{~mm} /$ queen cell. In contrast, control colonies produced $29.6 \pm 14.27$ queen cells/colony with a mean length of $10.3 \pm 0.25 \mathrm{~mm} /$ queen cell. Results showed significant differences among the number of queen cells produced from the three feed groups and that in control. On the other hand, there were no significant differences among the means of queen cell length. It has been noticed that Feeding colonies with different diets (A, B,
C) had a number of queen cells more than those of the control due to the good quality of proteins in diet, which lead to activate bee colonies to increase the number of worker bees inside the colonies.

\section{3- Effect of each feeding diet on honey productionduring citrus season of 2016}

Results in Table (3) referred to the total produced honey and its mean for each group of colonies. As for those fed on diet (A), the total honey production during citrus season was a mean of $6.82 \mathrm{~kg} /$ colony. Colonies fed on diet (B) produced with a mean of 5.54 $\mathrm{kg} /$ colony. The third group of colonies provided with diet (C) gave a mean of $5.64 \mathrm{~kg} /$ colony. The least a mean of honey production was the control colonies a mean of $4.08 \mathrm{~kg} /$ colony). Results significant differences among the four groups. The effect of different diets could be arranged in a decending order as follows: soybean $>$ yellow corn $\geq$ chick peas $>$ control.

\section{4-Queen excluder system and honey production} during citrus, Clover and cotton season of 2015

The queen excluder system was used to exclude a queen within two brood frames in the same colony and the other frames were left for workers to put and store nectar during citrus, clover and cotton nectar seasons. The produced honey was then determined to evaluate the effect of the queen excluding system. Table (4) showed a comparison between the colonies where the queen excluder system was applied on and those without that queen excluder system (the control) through the three nectar seasons of citrus, clover and cotton.

Table 2. Queens cells number and length after feeding on different diets during 2016 season

\begin{tabular}{lcc}
\hline Supplementary diets & Mean No. of queen cells & Mean of Queen length (mm) \\
\hline (A) & $138.6^{\mathrm{a}} \pm 5.65$ & $14.9 \pm 0.38$ \\
(B) & $32.0^{\mathrm{b}} \pm 17.84$ & $10.1 \pm 0.21$ \\
(C) & $114.6^{\mathrm{a}} \pm 5.62$ & $12.1 \pm 0.50$ \\
Control (D) & $29.6^{\mathrm{b}} \pm 14.27$ & $10.3 \pm 0.25$ \\
L.S.D & 36.274 & - \\
\hline
\end{tabular}

\#Soybean (A), chickpeas (B) and yellow corn (C)

*Means followed with the same letter (s) for each experimental month are not significantly different.

Table 3. Effect of feeding diets on honey production during spring of 2016 season

\begin{tabular}{lcc}
\hline \multicolumn{1}{c}{ Supplementary feeding } & $\begin{array}{c}\text { Total honey production } \\
(\mathbf{k g})\end{array}$ & $\begin{array}{c}\text { Mean weight of honey production } \\
(\mathbf{k g})\end{array}$ \\
\hline (A) & $34.1 \pm 0.33$ & $6.82^{\mathrm{a}}$ \\
(B) & $27.7 \pm 0.66$ & $5.54^{\mathrm{b}}$ \\
(C) & $28.2 \pm 0.38$ & $5.64^{\mathrm{ab}}$ \\
Control (D) & $20.4 \pm 0.17$ & $4.08^{\mathrm{c}}$ \\
L.S.D & - & 1.2755 \\
\hline
\end{tabular}

\#Soybean (A), chickpeas (B) and yellow corn (C)

*Means followed with the same letter (s) for each experimental month are not significantly different. 
Table 4. Honey production after using the queen excluder system in 2015 season

\begin{tabular}{lccc}
\hline Nectar season & Excluder & $\begin{array}{c}\text { Total weight of produced honey } \\
\text { (kg/10 colonies) }\end{array}$ & $\begin{array}{c}\text { Mean weight of honey } \\
\text { production }(\mathbf{k g})\end{array}$ \\
\hline Citrus & A\# & 91.45 & $9.15^{\mathrm{a}} \pm 0.17$ \\
& B & 52.00 & $5.20^{\mathrm{b}} \pm 0.15$ \\
Clover & A & 53.78 & $5.38^{\mathrm{a}} \pm 0.41$ \\
& B & 38.00 & $3.80^{\mathrm{b}} \pm 0.20$ \\
Cotton & A & 43.14 & $4.31^{\mathrm{a}} \pm 0.33$ \\
& B & 32.00 & $3.20^{\mathrm{b}} \pm 0.13$ \\
\hline
\end{tabular}

\#A=with excluder and $\mathrm{B}=$ without excluder

*Means followed with the same letter (s) for each experimental month are not significantly different.

In citrus season, the total weight of produced honey due to queen excluder system was $91.45 \mathrm{~kg} / 10$ colonies with a mean of $9.15 \pm 0.17 \mathrm{~kg} /$ colony as compared with the control colonies in the same season, which produced a honey production of $52.00 \mathrm{~kg} / 10$ colonies with a mean of $5.20 \pm 0.15 \mathrm{~kg} /$ colony. That there were significant differences among the means of produced honey in case of using queen excluder and the control. In clover season, the total weight of honey in colonies with excluder was $53.78 \mathrm{~kg}$ with a mean of $5.38 \pm 0.41$ $\mathrm{kg} /$ colony and the control colonies had a total weight of honey of $38.00 \mathrm{~kg}$ with a mean of $3.80 \pm 0.20 \mathrm{~kg} /$ colony, and the difference between both treatments was significant.

Through the cotton season, the colonies that had a queen excluder system produced a total honey weight of of $43.14 \mathrm{~kg}$ of $4.31 \pm 0.33 \mathrm{~kg} /$ colony, as compared to the control colonies $(32.00 \mathrm{~kg} 3.20 \pm 0.13 \mathrm{~kg} /$ colony), and the differences was significant between them. Results are in agreement with those reported by Hayes et al. (1985) and Moeller (1980) who indicated that beekeepers are using queen excluder to manage the colony and to decrease the humidity inside colonies especially in winter time, in addition to increasing honey production in summer season where the managed honey bees have economic importance with other hive products.

\section{REFERENCES}

Aly, M. Z., K. S. Osman, M. M. Karem, and W. A. El-Sayeh. 2014 New formula of pollen supplemental diets to study honey bee (Apis mellifera carnica) attractiveness. Egypt. Acad. J. Biol. Sci.: Entomol., 7(2): 47-55.

Amro, A., M. Omar and A. Al-Ghamdi. 2016. Influence of different proteinaceous diets on consumption, brood rearing, and honey bee quality parameters under isolation conditions. Turk. J. Vet. Ani. Sci., 40(4):468-475.

Brodschneider, R. and K. Crailsheim K. 2010. Nutrition and health in honey bees. Apidologie, 41: 278-294.
Hayes, G. W., J. R. Dadant, I. Wayland and I. Michigan. 1985. Queen excluder or honey excluder?. Amer. Beekeeping J., 564-567.

Herbert, E. W. Jr. 1992. Honey bee nutrition. In: The Hive and the Honey Bee. Graham, J.M. (editor) $1^{\text {st }}$ ed. Hamilton, IL, USA: Dadant and Sons, 197-233.

Maheshwari, J. K. 2003. Endangered pollinators. Environ. News Arch., 9: 32-45.

Mahmood, R., Elizabeth S. Wagchoure and G. Sarwar. 2013. Influence of supplemental diets on Apis mellifera L. colonies for honey production. Pak. J. Agric. Res., 26 (4):290-294

Manila, H. R. and G. W. Otis. 2006. Influence of pollen diet in spring on development of honey bee (Hymenoptera: Apidae) Colonies. J. Econ. Entomol., 99(3):604-613.

Moeller, F. E. 1980. Managing colonies for high honey yields. Research entomologist science and education administration (deceased) beekeeping in the United States. Agriculture handbook No. 335(10):64-72.

Morris, O. 2012. Managing honey bee populations for greater honey production. https://wasba.org/wp/wpcontent/uploads/2012/11.

Nuru, A., A. A. Al-Ghamdi , M. Hailu , A. G. Shenkute, M. J. Ansari , H. R. Hepburn and S. E. Radloff. 2013. Queen excluders enhance honey production in African honey bees. Apis mellifera, by limiting brood rearing during peak nectar flow. J. Apicul. Res., 52(5):184-189.

Pande, R. and A. K. Kamatak. 2014. Germinated pulses as a pollen substitute for dearth period management of honey bee colonies. Current Biotica, 8(2): 142-150.

Rezaei, A., M. G. Paghgale, M. M. S. Babak and M. Ghanjkhanio. 2015. Protein supplement ensiling effects of ensiling on palatability, body protein, brood rearing and population growth of honey bee colony (Apis mellifera). Iran. J. Ani. Sci., (1JAS) 46(3): 345-350.

Sihag, R. C. and M. Gupta. 2013. Testing the effects of some pollen substitute diets on colony build up and economics of beekeeping with Apis mellifera L. J. Entomol., 10(3): 120- 35 . 
Usha, P., S. V. Goswami and M. S. Khan. 2014. Exploration of various flours as pollen substitutes for Apis mellifera $\mathrm{L}$. during dearth period at

Hassona,N.M. 2006 Efficiency of The Italian honey bee queen Apis. mellifera.L )
Tarai region of Uttarakhand, India. J. Appl. Nat. Sci., $6(2): 812-815$.

(SAS).2004 statistical Analysis system users Cary. North Carolina, USA

\section{الملغص العربي}

\section{تعزيز إنتاج العسل في خلايا النحل في مصر}

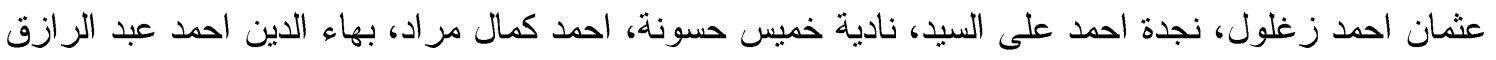

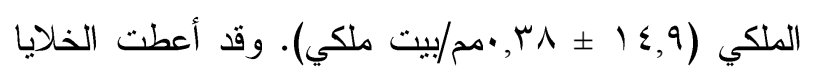

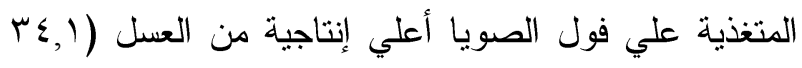

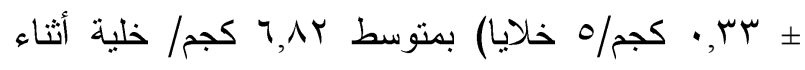

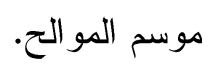

وقد أُستخدمت طريقة حجز الملكة كطريقة ثانية لــزيادة إنتاج العسل خلال مواسم الفيض في الموالح و البرسيم العزئ

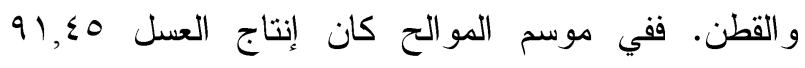

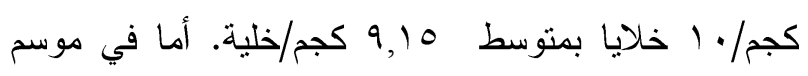

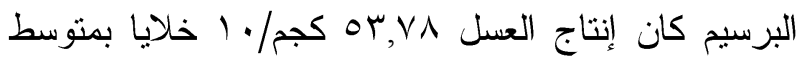

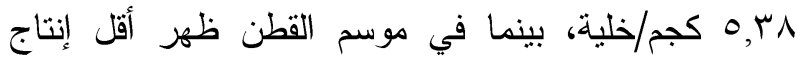

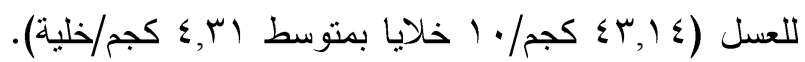

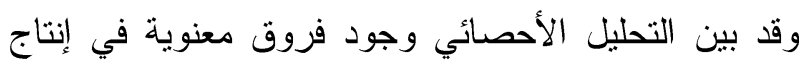
العسل بإستخدام حاجز الملكات بالمقارنة مع عدم إستخدامه.
تم استخدام طريقتين تطبيقيتين لزيادة إنتاج العسل في خلايا النحل في مصر حيث تم تطبيق الطريقة الأولي في

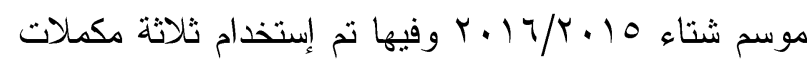

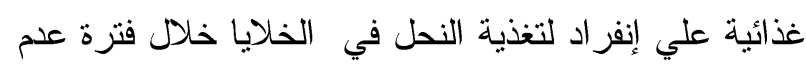
وجود أوتوافر الرحيق وهذه المكملات هي دقيق كل من

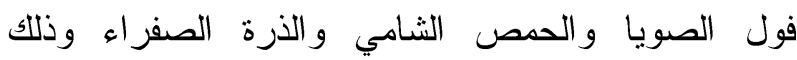
بغرض زيادة الإنتاج في هذه الفترة. وقد اظهرت النتائج

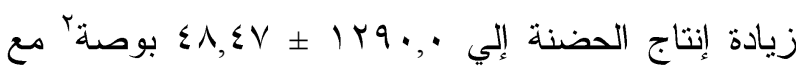

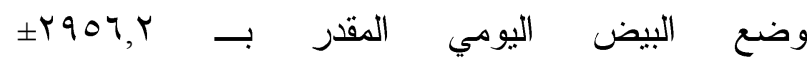
1/l/ ابيض/خلية من خلايا النحل المتغذية علي فول

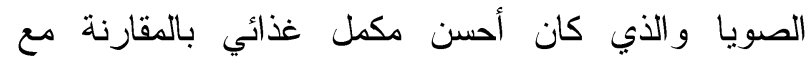
الحمص الثامي و الذرة الصفراء. علاوة علي ذلك أعطي

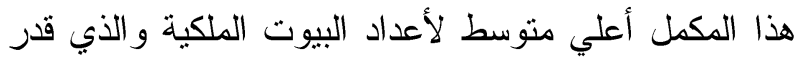

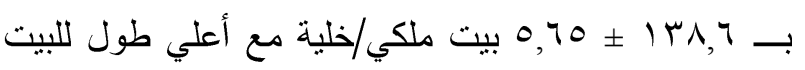

